\title{
Chemical composition, antibacterial activity and related mechanism of valonia and shell from Quercus variabilis Blume (Fagaceae) against Salmonella paratyphi a and Staphylococcus aureus
}

\author{
Dan Zhou ${ }^{\dagger}$, Ze-Hua Liư ${ }^{\dagger}$ Dong-Mei Wang ${ }^{*}$, Deng-Wu Li, Li-Na Yang and Wei Wang
}

\begin{abstract}
Background: Plant secondary metabolites and phytochemicals that exhibit strong bioactivities have potential to be developed as safe and efficient natural antimicrobials against food contamination and addressing antimicrobial resistance caused by the overuse of chemical synthetic preservative. In this study, the chemical composition, antibacterial activities and related mechanism of the extracts of the valonia and the shell of Quercus variabilis Blume were studied to determine its potential as a safe and efficient natural antimicrobial.

Methods: The phenolic compositions of valonia and shell extracts were determined by folin-ciocalteau colourimetric method, sodium borohydride/chloranil-based assay and the aluminium chloride method and then further identified by the reverse-phase HPLC analysis. The antibacterial activities of valonia and shell extracts were evaluated by the agar disk diffusion method and agar dilution method. The related antibacterial mechanism was explored successively by the membrane of pathogens effect, phosphorous metabolism, whole-cell proteins and the microbial morphology under scanning electron microscopy.

Results: The n-butanol fraction and water fraction of valonia along with n-butanol fraction of the shell contains enrich phenolics including ellagic acid, theophylline, caffeic acid and tannin acid. The n-butanol fraction and ethanol crude extracts of valonia exhibited strong antibacterial activities against Salmonella paratyphi A (S. paratyphi A) and Staphylococcus aureus (S. aureus) with the DIZ values ranged from $10.89 \pm 0.12$ to $15.92 \pm 0.44$, which were greater than that of the Punica granatum (DIZ: $10.22 \pm 0.18$ and $10.30 \pm 0.21$ ). The MIC values of the n-butanol fraction and ethanol crude extracts of valonia against S. paratyphi A and S. aureus were $1.25 \mathrm{mg} / \mathrm{ml}$ and $0.625 \mathrm{mg} /$ $\mathrm{ml}$. The related antibacterial mechanism of n-butanol fraction and ethanol crude extracts of valonia may be attributed to their strong impact on membrane permeability and cellular metabolism. Those extracts exhibited strong antibacterial activity according to inhibit the synthesis of bacterial proteins and seriously change morphological structure of bacterial cells.

Conclusions: The n-butanol fraction and ethanol crude extracts of valonia had reasonably good antibacterial activities against S. paratyphi A and S. aureus. This study suggests possible application of valonia and shell as natural antimicrobials or preservatives for food and medical application.
\end{abstract}

Keywords: Quercus variabilis, S. paratyphi a, S. aureus, Antibacterial mechanism

\footnotetext{
* Correspondence: dmwli@163.com

†Dan Zhou and Ze-Hua Liu contributed equally to this work.

College of Forestry, Northwest A \& F University, Yangling 712100, Shaanxi,

China
}

(c) The Author(s). 2019 Open Access This article is distributed under the terms of the Creative Commons Attribution 4.0 International License (http://creativecommons.org/licenses/by/4.0/), which permits unrestricted use, distribution, and reproduction in any medium, provided you give appropriate credit to the original author(s) and the source, provide a link to the Creative Commons license, and indicate if changes were made. The Creative Commons Public Domain Dedication waiver (http://creativecommons.org/publicdomain/zero/1.0/) applies to the data made available in this article, unless otherwise stated. 


\section{Highlights}

- Valonia and shell from Quercus variabilis possessed rich phenolics and tannins.

- Antibacterial activity of valonia and shell extracts were studied.

- VEE and VBF exhibited the strongest inhibition on S. paratyphi A and S. aureus and were selected to investigate the antibacterial mechanism.

- Integrity and permeability of cell membrane, phosphorus consumption, SDS-PAGE of protein patterns and cell microstructure were determined.

\section{Background}

Plant secondary metabolites, or phytochemicals produced that exhibit antibacterial, antioxidant and antineoplastic activities have long been adopted to develop novel, safe and efficient natural antimicrobials for alternative medicine $[1,2]$. Food contamination caused by the pathogenic bacteria such as Escherichia coli, Listeria monocytogenes, Salmonella, Staphylococcus affect food quality and represent a serious health risk to human intestines, urinary tract infection and food poisoning [3-6]. However, some chemical synthetic preservatives used in food control may cause respiratory diseases or other health risks $[7,8]$. Overuse of antibiotics may result in the problem of antimicrobial resistance $[9,10]$. Hence, recent research has focused on the search for natural antimicrobials from plants used as alternative medicines.

The Chinese cork oak, Q. variabilis, is a common warm-temperate deciduous broadleaf tree in East Asia and widely distributed in the north and east of China $[11,12]$. Q. variabilis contributes a lot to the development of economy and ecosystem for its timber, cork and water conservation. As a significant energy tree species in China, the single-tree additive biomass models have been established to predict biomass or carbon stocks of cork oak forests in North China [13].

Q. variabilis cork is unique for its valuable properties including low density, high elasticity, good heat and acoustic insulation properties, which resistance to chemical and microbial attack for the production of stoppers for wine and thermal and/or acoustic insulation materials $[14,15]$. The virgin and reproduction cork from $Q$. variabilis consist abundant suberin, lignin, extractives and polysaccharides $[16,17]$. The acorn of $Q$. variabilis is rich in starch, soluble sugar, tannin, protein, grease and coarse fibre without tannins, which is usually used as feed for pigs, cows and goats $[18,19]$. Leaves from different Quercus species contain polyphenols and natural triterpenoid that have the anti-inflammatory effects [20]. The acorn shell is used for produce activated carbon for the extraction as pigments. The valonia (cups of the acorn) contains approximately $28.45 \%$ tannin with a high purity of $77.64 \%$. Ellagic acid and luteoic acid were isolated and identified from the tannin in valonia which is widely applied as medicine and food field [21-23]. Four species of lignins have been identified in the valonia and the physicochemical properties while the antioxidant activities have also been studied [24].

The phytochemistry of the valonia and shell from $Q$. variabilis have been studied however with limited research on their biological activities. Furthermore, due to the large annual production of $Q$. variabilis, the valonia and shell are a major source of wastage to their limited utilization. The objectives of this study were therefore to: (1) to determine the phytochemical composition, including the total content of phenolic, flavonoid and tannins of valonia and shell extracts from $Q$. variabilis; (2) measure the antibacterial activities of the extracts and (3) further investigation of the mechanisms of specific antimicrobial action of two effective extracts against selectively screened bacteria to support the development and utilization of these waste by-products.

\section{Methods \\ Chemicals and microorganisms}

Folin-Ciocalteu Reagent, chloramphenicol (Beijing Solarbio Co., Ltd., China); ellagic acid, galic acid monohydrate, caffeic acid, quercetin and theophyline (Shanghai Winherb Medical Science Co., Ltd., China); tannin acid (Tianjin Dongliqu Tianda Chemical Co., Ltd., China); ethanol, methanol, petroleum ether, ethyl acetate, n-butanol, dimethyl sulfoxide (DMSO) (Chengdu Kelong Chemical Co., Ltd., China); sodium carbonate $\left(\mathrm{Na}_{2} \mathrm{CO}_{3}\right)$, sodium borohydride $\left(\mathrm{NaBH}_{4}\right)$, aluminum chloride $\left(\mathrm{AlCl}_{3}\right)$, hydrochloric acid, acetic acid, chloranil, vanillin, phosphomolybdic acid, sodium tungstate, and tetrahydrofuran (THF) (Tianjin Bodi Chemical Co., Ltd., China); chromatographic grade methanol and acetonitrile (Sigma-Aldrich Co., St. Louis, USA).

Muller Hilton Agar (MHA) and nutrient broth (NB) (Qingdao Hope Bio- Technology Co., Ltd., China).

$S$. aureus, Listeria monocytogenes (L. monocytogenes), S. paratyphi A, Salmonella typhimurium (S. typhimurium) and Salmonella, L. enteritidis (S. enteritidis) (Microbial Culture Collection Center of Guangdong Institute of Microbiology, China).

\section{Plant material and extracts preparation}

The valonia and shell of Q. variabilis were collected from Northwest A\&F University, Shaanxi province, China in September 2014. The voucher specimen was identified by the professor Dengwu $\mathrm{Li}$ and was deposited at Herbarium of the Northwest A\&F University, Yangling, China (WUK 0489424). Plant materials were air-dried under shade at room temperature then stored at $-20^{\circ} \mathrm{C}$ for further analysis. The valonia $(1.0 \mathrm{~kg})$ was extracted using $70 \%$ ethanol at room temperature for $12 \mathrm{~h}$ with a solid to liquid ratio of 1 : 10 and the extracted repeated 3 times. The ethanol crude 
extracts (VEE, 130.29 g) was filtered and evaporated to dryness and $6 \mathrm{~g}$ of VEE was stored for further analysis. The remaining VEE $(124.29 \mathrm{~g})$ suspended in water was further partitioned step by step by petroleum ether, ethyl acetate and n-butanol to give the petroleum ether extracts (VPEF, $2.65 \mathrm{~g}$ ), ethyl acetate extracts (VEAF, $8.23 \mathrm{~g}$ ), n-butanol extracts (VBF, $24.91 \mathrm{~g}$ ) and water extracts (VWF, $66.53 \mathrm{~g}$ ) [25].

Shell of Q. variabilis $(500 \mathrm{~g}$ ) was processed according to the above step and the ethanol crude extract (SEE, $6.00 \mathrm{~g}$ ), petroleum ether extracts (SPEF, $0.52 \mathrm{~g}$ ), ethyl acetate extracts (SEAF, $0.42 \mathrm{~g}$ ), n-butanol extracts (SBF, $4.07 \mathrm{~g}$ ) and water extracts (SWF, $3.97 \mathrm{~g}$ ) were obtained.

\section{Phytochemical profiles of valonia and shell extracts Determination of total phenolic (TPC) and flavonoid content (TFC)}

The TPC was determined using the Folin-Ciocalteau colourimetric method [26]. $200 \mu \mathrm{L}$ extracts $(0.4 \mathrm{mg} / \mathrm{ml})$ or different concentrations of gallic acid solution were mixed with $800 \mu \mathrm{L}$ deionized water to which $200 \mu \mathrm{L}$ Folin-Ciocalteu Reagent was added and boiled for $6 \mathrm{~min}$. $2 \mathrm{ml}$ of $7 \% \mathrm{Na}_{2} \mathrm{CO}_{3}$ and $1.6 \mathrm{ml}$ deionized water were added and left standing for $90 \mathrm{~min}$ at room temperature after which absorbance measured at $517 \mathrm{~nm}$. TPC was expressed as mg gallic acid equivalent per $1 \mathrm{~g}$ (dry weight). All samples were analyzed in triplicate.

The TFC was determined by the sodium borohydride/ chloranil-based assay in samples at the concentration of $2.0 \mathrm{mg} / \mathrm{ml} \mathrm{[26].} \mathrm{TFC} \mathrm{was} \mathrm{expressed} \mathrm{as} \mathrm{millimole} \mathrm{quer-}$ cetin equivalent per $100 \mathrm{~g}$ (dry weight). All the samples were analyzed in triplicate.

\section{Determination of total tannin content (TTC)}

The TTC was assessed using the aluminium chloride method [27]. $1.0 \mathrm{ml} \mathrm{F-D} \mathrm{chromogenic} \mathrm{agent} \mathrm{and} 1.0 \mathrm{ml}$ extracts $(1.0 \mathrm{mg} / \mathrm{ml})$ or different concentrations of tannin acid solution were mixed, $1.0 \mathrm{ml} 1 \mathrm{~mol} / \mathrm{L} \mathrm{Na}_{2} \mathrm{CO}_{3}$ was then added to this and made up to volume using $80 \%$ ethanol. The solution was allowed stand for $30 \mathrm{~min}$ and the absorbance measured at $720 \mathrm{~nm}$. TTC was expressed as mg tannic acid equivalent per $1 \mathrm{~g}$ (dry weight). All the samples were analyzed in triplicate.

\section{Reverse-phase HPLC analysis of the main compounds}

Samples were filtered through $0.22 \mu \mathrm{m}$ membrane filters and then analyzed by using an Agilent Technologies 1260 series liqudi chromatograph (RP-HPLC). The quantification was carried out on a SB-C18 reverse phase column ( $5 \mu \mathrm{m}, 4.6$ by $250 \mathrm{~mm}$ ) at ambient temperature. The mobile phases consisted of water ( $0.2 \%$ acetic acid, solvent $\mathrm{A})$ and acetonitrile (solvent $\mathrm{B}$ ). The gradient elution program was as follows: $5 \%$ B (0 min), 10\% B (0-20 min), 20\% B (20-30 min), 25\% B (30-35 min), 40\% B (35-45 min), 80\% B (45-60 min). The mobile phase flow rate was kept at
$0.8 \mathrm{ml} / \mathrm{min}$. The injection volume was $20 \mu \mathrm{L}$ and the chromatogram was measured at $254 \mathrm{~nm}$. Analyses were performed in triplicate.

\section{Antibacterial activities of valonia and shell extracts Agar disk diffusion method}

The agar disk diffusion method was employed for the evaluation of antibacterial activities [28]. The extracts (5 $\mathrm{mg} / \mathrm{ml}$ ) were dissolved in $2 \%$ DMSO. The ethonal extracts of Punica granatum and ellagic acid were used as positive controls and the DMSO as negative control. The zone of the inhibition (DIZ) was measured in millimeters and ranked as follows: not sensitive for zone diameters equal to $8 \mathrm{~mm}$ or below; sensitive for zone diameters between 8 and $14 \mathrm{~mm}$, very sensitive for zone diameters between 14 and $20 \mathrm{~mm}$. Reported inhibition zones were the average values calculated triplicate.

Minimum inhibition concentration (MIC) and minimum bactericidal concentration (MBC).

The MIC of ten polarity fractions of valonia and shell from $Q$. variabilis were determined by agar dilution method [29]. A series of two-fold dilutions of each extracts was dissolved in 2\% DMSO to obtain the concentration from 1.56 to $100 \mathrm{mg} / \mathrm{ml}$. Each of the tested sterile petri dishes contained $18 \mathrm{ml} \mathrm{MHA}$ and $2 \mathrm{ml}$ extracts. $3 \mu \mathrm{L}$ bacterial inoculum $\left(10^{6} \mathrm{CFU} / \mathrm{ml}\right)$ was placed on plate for each dilution and then incubated at $37^{\circ} \mathrm{C}$ for $24 \mathrm{~h}$. Negative control was performed using $2 \%$ DMSO. The MIC was the lowest concentration of the extracts in which no growth on the plate was observed. Then the plates beyond MIC value continued incubated at $37^{\circ} \mathrm{C}$ for $24 \mathrm{~h}$. The concentration at which no visible growth was seen was determined as the MBC [30].

Two effective antibacterial extracts were selected to investigate the antibacterial mechanism against two screened bacteria.

\section{The effect of VBF and VEE on the membrane of pathogens \\ Leakage of proteins}

The bacterial suspension $\left(10^{8} \mathrm{CFU} / \mathrm{ml}\right)$ was added into the NB with $1 \times$ MIC VEE and VBF. The control was conducted with $2 \%$ DMSO. The cultures were incubated at $37^{\circ} \mathrm{C}$ with shaking at $180 \mathrm{rpm}$ for $1,4,8$ and $24 \mathrm{~h}$. Then centrifuged at $10,000 \times \mathrm{g}$ for $15 \mathrm{~min}$ and the precipitation was added $500 \mu \mathrm{L} \mathrm{NaCl}(0.9 \%)$ and then centrifuged at 10 , $000 \times \mathrm{g}$ for $5 \mathrm{~min}$. The supernatant liquid was immediately determined by micro protein assay [31].

\section{Leakage of nucleic acid}

The bacterial suspension $\left(10^{8} \mathrm{CFU} / \mathrm{ml}\right)$ was added into the $\mathrm{NB}$ at $37^{\circ} \mathrm{C}$ with shaking at $180 \mathrm{rpm}$ overnight. Then centrifuged at $10,000 \mathrm{~g}$ for $5 \mathrm{~min}$ and the precipitation were diluted with $7 \mathrm{~mL} \mathrm{NaCl}(0.9 \%)$. The mixture was exposure to 
$1 \times$ MIC VEE and VBF for $1,4,8$ and $24 \mathrm{~h}$. The cultures were immediately filtered with $0.2 \mu \mathrm{m}$ syringe filters to remove the bacteria. Then the supernatant was diluted appropriately and optical density at $260 \mathrm{~nm}$ was recorded [32].

\section{Leakage of total sugar in the medium}

The bacterial suspension $\left(10^{8} \mathrm{CFU} / \mathrm{ml}\right)$ were added into the $\mathrm{NB}$ at $37^{\circ} \mathrm{C}$ with shaking at $180 \mathrm{r} / \mathrm{min}$ overnight. 1 $\mathrm{mL}$ suspension was added into $7 \mathrm{ml} \mathrm{NB}$ with $1 \times \mathrm{MIC}$ VEE and VBF. The mixture was incubated for $1,4,8$ and $24 \mathrm{~h}$. The samples were centrifuged at $10,000 \mathrm{~g}$ for $5 \mathrm{~min}$ to obtain the precipitation. $50 \mu \mathrm{L}$ of the precipitation and $200 \mu \mathrm{L}$ anthrone were added and then cooled in ice water for $5 \mathrm{~min}$. Then the mixture was water bathed for $10 \mathrm{~min}$. The absorbance was measured at 620 $\mathrm{nm}$ by microplate reader [33].

\section{The effect of VEE and VBF on the phosphorous metabolism of bacteria}

The bacterial suspension $\left(10^{8} \mathrm{CFU} / \mathrm{ml}\right)$ was added into the $\mathrm{NB}$ at $37^{\circ} \mathrm{C}$ with shaking at $180 \mathrm{rpm}$ overnight. Then centrifuged at $5000 \mathrm{~g}$ for $10 \mathrm{~min}$ and the precipitation were diluted with $0.1 \mathrm{~mol} / \mathrm{L}$ phosphate buffer $\left(10^{6} \mathrm{CFU} /\right.$ $\mathrm{ml}$ ). Add $2 \mathrm{ml}$ glucose and $800 \mu \mathrm{L}$ phosphoric acid standard solution into $2 \mathrm{ml}$ bacterial suspension. Then $800 \mu \mathrm{L}$ of VEE and VBF $(1 \times \mathrm{MIC})$ were added and the mixture were incubated for $0,1,2,4,6,8$ and $12 \mathrm{~h} .0 .1$ $\mathrm{ml}$ suspension and $1 \mathrm{ml}$ trichloroacetic acid-ferrous sulfate were mixed and stand for $10 \mathrm{~min}$, then centrifuged at $5000 \mathrm{~g}$ for $5 \mathrm{~min} .2 \mathrm{ml}$ supernatant and $50 \mu \mathrm{L}$ ammonium molybdate were mixed and placed in $30^{\circ} \mathrm{C}$ for 15 min. The mixture was measured at $630 \mathrm{~nm}$ by microplate reader [34].

\section{SDS-PAGE of whole-cell proteins}

SDS-PAGE of the bacterial proteins was carried out according to the method [35]. After exposure to $1 \times$ MIC VEE and VBF for $24 \mathrm{~h}$, the bacterial cells samples were centrifuged at $10,000 \mathrm{~g}$ for $5 \mathrm{~min}$. The cell pellet was rinsed and washed three times with $0.01 \mathrm{~mol} / \mathrm{L}$ phosphate buffer (PBS) and then collected by centrifugation at $5000 \mathrm{~g}$ for $5 \mathrm{~min}$. The buffer was added into the cells mixture and boiled for $5 \mathrm{~min}$ and then cooled on ice. The control was run without the extracts. Then the supernatant of each sample was collected for the SDSPAGE analysis. After electrophoresis, the gel was stained with coomassie brilliant blue R-250 and then decolorized to obtain the separated protein bands.

\section{Scanning electron microscopy (SEM) analysis}

To determine the morphological changes of bacteria treated by the extracts, SEM studies were carried out [36]. Logarithmic growth phase cells of two tested bacteria were treated with $1 \times$ MIC VEE and VBF. The control (without the samples) and samples were incubated at $37^{\circ} \mathrm{C}$ for $24 \mathrm{~h}$. The cells were harvested by centrifugation $(10,000 \mathrm{~g}, 10$ $\mathrm{min}$ ) and washed twice with $0.1 \mathrm{M} \mathrm{PBS}$ and then fixed with $2.5 \%(\mathrm{v} / \mathrm{v})$ glutaraldehyde in PBS overnight at $4{ }^{\circ} \mathrm{C}$. After centrifugation, the cells were further dehydrated using a graded series of ethanol (30, 50, 70, 80, 90 and 100\%) and drying with hexamethyl-disilazane. The samples were fixed on SEM support and then sputter-coated with gold under vacuum, followed by microscopic examinations using SEM.

\section{Results}

\section{Contents of TPC, TTC and TFC}

Plant polyphenols are considered to possess biological activities such as antioxidant properties and antibacterial activities. Results regarding TPC, TFC and TTC of valonia extracts (VEE, VPEF, VEAF, VBF and VWF) and shell extracts (SEE, SPEF, SEAF, SBF and SWF) from $Q$. variabilis are shown in Table 1 . The contents of TPC were ranged from 68.64 to $711.46 \mathrm{mg}$ GAE/g. The highest level of TPC was found in VWF $(711.46 \pm 7.32 \mathrm{mg}$ GAE/g), followed by VBF $(673.66 \pm 1.22 \mathrm{mg} \mathrm{GAE} / \mathrm{g})$ and $\operatorname{VEE}(641.95 \pm 4.88 \mathrm{mg} \mathrm{GAE} / \mathrm{g})$. The TPC of the rest of

Table 1 Total phenolic, flavonoid and tannins content of valonia and shell from Q. variabilis

\begin{tabular}{lllll}
\hline Organ & Extracts & TPC $(\mathrm{mg} \mathrm{GAE} / \mathrm{g})$ & TFC $(\mathrm{mmol}$ QUE/100 g) & TTC (mg TAE/g) \\
\hline Valonia & VEE & $641.95 \pm 4.88$ & $19.77 \pm 0.07$ & $142.33 \pm 0.51$ \\
& VPEF & $188.05 \pm 1.52$ & $29.21 \pm 0.02$ & $40.56 \pm 0.33$ \\
& VEAF & $529.76 \pm 2.44$ & $27.37 \pm 0.06$ & $237.49 \pm 1.84$ \\
& VBF & $673.66 \pm 1.22$ & $16.98 \pm 0.03$ & $258.02 \pm 3.34$ \\
& WWF & $711.46 \pm 7.32$ & $22.01 \pm 0.00$ & $228.47 \pm 1.50$ \\
Shell & SEE & $461.49 \pm 6.10$ & $31.05 \pm 0.01$ & $138.10 \pm 0.33$ \\
& SPEF & $68.64 \pm 3.68$ & $24.63 \pm 0.06$ & $57.26 \pm 1.00$ \\
& SEAF & $426.71 \pm 1.83$ & $31.35 \pm 0.05$ & $205.25 \pm 3.67$ \\
& SBF & $593.17 \pm 3.66$ & $45.82 \pm 0.02$ & $253.35 \pm 4.51$ \\
& SWF & $512.68 \pm 4.88$ & $23.75 \pm 0.03$ & $218.11 \pm 1.17$ \\
\hline
\end{tabular}

Each value represented in tables are means \pm SD $(n=3)$. 
extracts phase were below $600 \mathrm{mg}$ GAE/g. The TPC contents in valonia extracts were higher than that of shell, the TPC contents in VEE were higher than that of SEE as well as the VEAF and SEAF.

The contents of TFC ranged from 16.98 to $45.82 \mathrm{mmol}$ QUE/100 g. The highest level of TFC was found in SBF $(45.82 \pm 0.02 \mathrm{mmol}$ QUE/100 g), followed by SEAF $(31.35 \pm 0.05 \mathrm{mmol}$ QUE/100 g) and SEE $(31.05 \pm 0.01$ mmol QUE $/ 100 \mathrm{~g}$ ). The TFC of the rest of extractions were below $30 \mathrm{mmol}$ QUE/100 g. The TFC of the same solvent extract phase of shell were higher than that of valonia except petroleum ether extract.

The contents of TTC were ranged from 40.56 to 258.02 $\mathrm{mg} \mathrm{TAE} / \mathrm{g}$ and the highest level of it was found in VBF $(258.02 \pm 3.34 \mathrm{mg} \mathrm{TAE} / \mathrm{g})$, followed by SBF $(253.35 \pm 4.51$ $\mathrm{mg}$ TAE/g), VEAF $(237.49 \pm 1.84 \mathrm{mg}$ TAE/g). The TTC of the other extracts were below $230 \mathrm{mg} \mathrm{TAE} / \mathrm{g}$. The valonia extracts from same solvent possessed higher TTC contents than that of shell except of petroleum ether extract. It suggested that there were differences of chemical composition content among different parts of the same plant.

\section{Contents of four compounds by HPLC analysis}

Chromatograms of valonia and shell extracts from Q. variabilis were analyzed by HPLC method (Table 2). Four compounds in valonia extracts were identified as ellagic acid, tannin acid, theophylline and caffeic acid and the contents were determined (Fig. 1, Table 3). The precision of the analytical method was determined by assaying six replicates of the standard compounds, and the relative standard deviations (RSD) of the peak areas were estimated to be 0.20 $0.41 \%(n=6)$. The repeatability of the method was determined by injecting the same sample six times. The areas of the peaks were recorded, and the RSD of the areas varied from 1.11 to $2.75 \%(n=6)$. To confirm the accuracy of the method, a recovery experiment was performed by mixing quantified samples with specific quantities of standard compounds. The average percentages of recovery of the four compounds ranged from 0.34 to $2.75 \%(n=6)$.

In valonia and shell extracts, no targeted compound were detected in SPEF, while only ellagic acid (1.02 \pm $0.09 \mathrm{mg} / \mathrm{g}$ ) was tested in SBF. After extraction separation, VEAF exhibited the highest contents of ellagic acid $(74.57 \pm 3.02 \mathrm{mg} / \mathrm{g})$, followed by SEAF $(22.66 \pm 0.23$ $\mathrm{mg} / \mathrm{g})$ and VEE $(18.95 \pm 0.20 \mathrm{mg} / \mathrm{g})$. Tannin acid was primarily concentrated in SEAF $(16.96 \pm 1.87 \mathrm{mg} / \mathrm{g})$ and $\operatorname{VEAF}(13.41 \pm 0.47 \mathrm{mg} / \mathrm{g})$. Theophylline and caffeic acid were especially high in VBF, with the content of $66.23 \pm$ $2.21 \mathrm{mg} / \mathrm{g}$ and $5.63 \pm 0.57 \mathrm{mg} / \mathrm{g}$. The valonia contained higher total content of compounds compared with the shell. Ellagic acid, theophylline and caffeic acid in valonia were higher that of shell from same solvent extraction.

\section{Antibacterial activities of valonia and shell extracts Preliminary screening of strains}

Natural phenolic products may exhibit a wide range of biological effects [8]. The results indicated that total phenolic and tannin were rich in the extracts of valonia and shell from $Q$. variabilis. Thus the antibacterial activities of the ethanol extracts against five bacteria were shown in Table 4. The diameters of inhibition zones (DIZ) were exerted by the various extracts towards challenged microorganisms. The control (2\% DMSO) did not inhibit any of microorganisms tested. The results indicated that valonia was active against $S$. paratyphi A, with the DIZ of 12.37 $\mathrm{mm}$, followed by $S$. aureus (10.89), S. typhimurium (10.32), S. enteritidis (9.52) and L. monocytogenes (9.36). In addition, Punica granatum peel was used as positive control due to its rich content of phenolics and flavonoids that displayed strong inhibition effects on the food-borne pathogens, including L. monocytogenes, S. aureus and $S$. enteritidis [37]. The ethanol extract of Punica granatum peel possessed strong activities against $L$. monocytogenes (DIZ $10.83 \mathrm{~mm}$ ) than valonia and weaker antibacterial activities against the other four bacteria than valonia. The inhibition effects of shell extracts on $S$. aureus and $S$. paratyphi A were weaker than that of valonia. Chloramphenicol $(5 \mu \mathrm{g} / \mathrm{ml})$ as positive control was active against tested microorganisms, and the inhibition effects were 24 times to valonia and shell.

In conclusion, the results indicated that the extracts of valonia and shell from Q. variabilis were bioactive against $S$. aureus and $S$. paratyphi A. Thus the $S$. aureus and $S$. paratyphi A were chosen for further research of the antibacterial activities and related mechanism.

Table 2 Method validation for the quantitative determination of four compounds using RP-HPLC

\begin{tabular}{|c|c|c|c|c|c|c|c|c|c|}
\hline \multirow{2}{*}{$\begin{array}{l}\text { Peak } \\
\text { no. }\end{array}$} & \multirow[t]{2}{*}{ Compounds } & \multirow{2}{*}{$\begin{array}{l}\text { Retention } \\
\text { time }\end{array}$} & \multirow[t]{2}{*}{ Regression equation } & \multicolumn{2}{|c|}{ Precision experiment } & \multicolumn{2}{|l|}{ Repeatability } & \multicolumn{2}{|c|}{ Recovery experiment } \\
\hline & & & & Area of peak & $\operatorname{RSD}(\%)$ & Area of peak & $\begin{array}{l}\text { RSD } \\
(\%)\end{array}$ & $\begin{array}{l}\text { Average } \\
\text { recovery rate }\end{array}$ & $\begin{array}{l}\text { RSD } \\
(\%)\end{array}$ \\
\hline 1 & tannin acid & 6.794 & $Y=19,106 x+31.263\left(R^{2}=0.9996\right)$ & $2492.6 \pm 10.1$ & 0.41 & $159.4 \pm 33.44$ & 2.09 & $105.57 \pm 1.75$ & 1.36 \\
\hline 2 & theophyline & 15.605 & $Y=30,252 x-13.334\left(R^{2}=0.9995\right)$ & $3753 \pm 5.9$ & 0.20 & $1346.8 \pm 53.74$ & 2.22 & $102.86 \pm 1.25$ & 1.18 \\
\hline 3 & caffeic acid & 27.98 & $Y=31,908 x+31.065\left(R^{2}=0.9994\right)$ & $4172.2 \pm 8.2$ & 0.20 & $625.26 \pm 17.25$ & 2.75 & $98.36 \pm 0.36$ & 0.34 \\
\hline 4 & ellagic acid & 35.447 & $Y=206,229 x+1865.8\left(R^{2}=0.9984\right)$ & $22,707.5 \pm 103.3$ & 0.34 & $20,841.7 \pm 232.01$ & 1.11 & $102.54 \pm 2.83$ & 2.75 \\
\hline
\end{tabular}

Values were expressed in mean \pm SD $(n=6)$. 

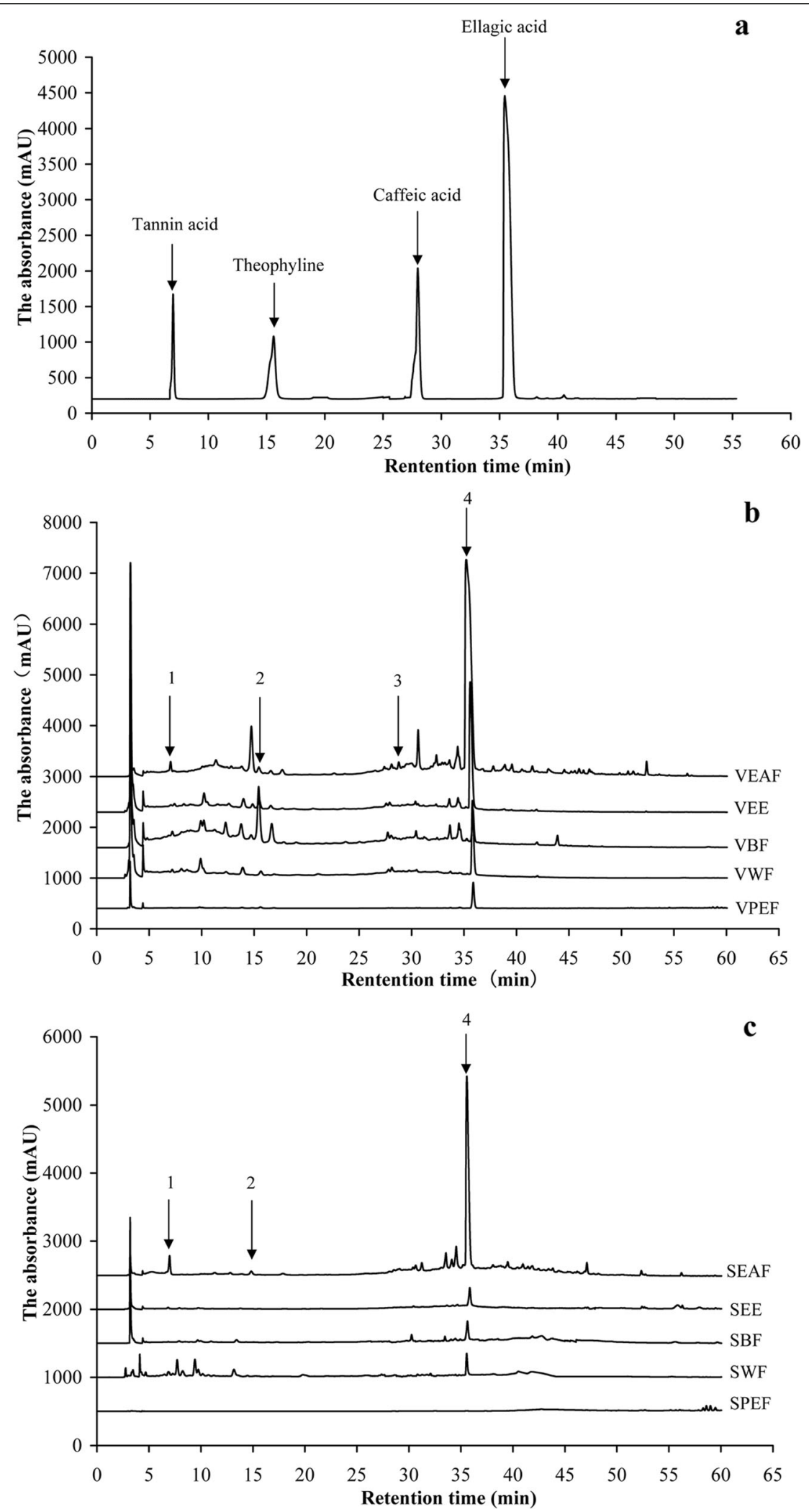

Fig. 1 Analytical HPLC chromatogram of reference substances (a) and compounds of extracts of valonia (b) and shell (c) from Q. variabilis 
Table 3 Contents of four compounds of valonia and shell extracts from Q. variabilis

\begin{tabular}{clllll}
\hline Organ & Extracts & \multicolumn{3}{l}{ Compound $(\mathrm{mg} / \mathrm{g})$} \\
\cline { 3 - 6 } & & Ellagic acid & Tannic acid & Theophyline & Caffeic acid \\
\hline Valonia & VEE & $18.95 \pm 0.20$ & $2.21 \pm 0.33$ & $9.58 \pm 0.27$ & $2.64 \pm 0.14$ \\
& VPEF & $2.17 \pm 0.04$ & $0.14 \pm 0.02$ & $1.39 \pm 0.03$ & $0.05 \pm 0.02$ \\
& VEAF & $74.57 \pm 3.02$ & $13.41 \pm 0.47$ & $20.17 \pm 0.003$ & $1.74 \pm 0.002$ \\
& VBF & $3.08 \pm 0.07$ & $6.41 \pm 0.76$ & $66.23 \pm 2.21$ & $5.63 \pm 0.57$ \\
& WWF & $8.68 \pm 0.25$ & $2.72 \pm 0.20$ & $5.18 \pm 0.33$ & $3.23 \pm 0.11$ \\
Shell & SEE & $0.90 \pm 0.11$ & $1.09 \pm 0.05$ & $0.15 \pm 0.005$ & $0.36 \pm 0.005$ \\
& SPEF & - & - & - & - \\
& SEAF & $22.66 \pm 0.23$ & $16.96 \pm 1.87$ & $0.28 \pm 0.002$ & $0.33 \pm 0.05$ \\
& SBF & $1.02 \pm 0.09$ & - & - & - \\
& SWF & $0.55 \pm 0.08$ & $3.37 \pm 0.06$ & $1.36 \pm 0.16$ & -
\end{tabular}

Each value represented in tables are means \pm SD $(n=3)$.

\section{Antibacterial activities of ten extracts against S. aureus and} S. paratyphi a

As shown in Table 5, the antibacterial activities of valonia and shell were measured. The DIZ against $S$. aureus were ranked as followed: VBF $(12.26 \mathrm{~mm})>\mathrm{VEAF}$ $(11.64 \mathrm{~mm})>\operatorname{VEE} \quad(10.89 \mathrm{~mm})>\operatorname{VWF} \quad(9.71 \mathrm{~mm})>\mathrm{SEE}$ $(8.99 \mathrm{~mm})>\operatorname{SWF} \quad(8.01 \mathrm{~mm})>\operatorname{SEAF} \quad(7.97 \mathrm{~mm})>\mathrm{SBF}$ $(7.06 \mathrm{~mm})$. For $S$. aureus, the petroleum ether extract had no inhibition effects. SEAF and SBF was not sensitive to $S$. aureus for DIZ equal to $8 \mathrm{~mm}$ or below. The others expressed sensitive activity for DIZ between 8 and $14 \mathrm{~mm}$. The antibacterial activities of valonia and shell against $S$. paratyphi A was ranked as followed: VBF $(15.92 \mathrm{~mm})>\operatorname{VEE} \quad(12.37 \mathrm{~mm})>\operatorname{VEAF} \quad(12.26 \mathrm{~mm})>$ $\operatorname{VWF}(10.25 \mathrm{~mm})>\operatorname{SEE}(9.62 \mathrm{~mm})>\operatorname{SEAF}(8.72 \mathrm{~mm})>$ SWF $(8.07 \mathrm{~mm})>\operatorname{SBF}(7.86 \mathrm{~mm})>\operatorname{VPEF}(7.62 \mathrm{~mm})$. VBF possessed very sensitive activity to $S$. paratyphi A for DIZ between 14 and $20 \mathrm{~mm}$. The antibacterial activity of VPEF and SBF against $S$. paratyphi A was not sensitive.

The antibacterial properties of the extracts were also evaluated by the MIC and MBC values. The control ( $2 \%$ DMSO) did not inhibit any of microorganisms. Among the extracts, VEE, VBF and VWF had better antibacterial effect on S. aureus and S. paratyphi A with the MIC values of $0.625 \mathrm{mg} / \mathrm{ml}$ and $1.25 \mathrm{mg} / \mathrm{ml}$. The $\mathrm{MBC}$ values were the same as MIC. Poor inhibitory activities were detected against the two strains in VPEF and SPEF $(\geq 10$ $\mathrm{mg} / \mathrm{ml}$ ). The antibacterial activities of valonia were stronger than shell extracts. The antibacterial activities showed that VEE and VBF had better inhibition effects on $S$. aureus and S. paratyphi A, so VEE and VBF were chosen to further study the mechanism.

\section{The effect of VBF and VEE on the membrane of $S$. aureus and S. paratyphi a \\ Leakage of proteins}

As shown in Fig. 2, VEE and VBF enhanced the leakage of proteins through the bacteria membrane. The leakage of proteins from S. paratyphi A were $2.31 \mu \mathrm{g} / \mathrm{ml}$ and $1.74 \mu \mathrm{g} / \mathrm{ml}$ when treated with VEE and VBF after $1 \mathrm{~h}$ incubation, which were higher than the control $(0.41 \mu \mathrm{g} /$ $\mathrm{ml})$. The leakage of proteins increased with the treatment time extension. The contents of leakage proteins of $S$. paratyphi A that treated with VEE reached the highest after $8 \mathrm{~h}(5.80 \mu \mathrm{g} / \mathrm{ml})$. For $S$. aureus, the leakage of proteins had the similar tendency like $S$. paratyphi A with the treatment of VEE. After $24 \mathrm{~h}$ incubation, the leakage of proteins decreased compared with $8 \mathrm{~h}$ and still higher than control. It suggested that the bacteria may entered into the decline phase and the bacteria amounts were reduced.

\section{The total sugar in the medium}

As Fig. 2 showed, after treated with VEE and VBF, the total sugar in the medium increased with the incubation time and reached the maximum at $24 \mathrm{~h}$. The total sugar leakage of $S$. paratyphi A that treated with VEE and VBF were 80.32 and $86.32 \mu \mathrm{g} / \mathrm{ml}$. For $S$. aureus, VEE caused the leakage of total sugar with the content of $150.53 \mu \mathrm{g} / \mathrm{ml}$. The total sugar of $S$. aureus that treated with VBF was $166.47 \mu \mathrm{g} / \mathrm{ml}$. The total sugar of the control decreased with the incubation time because the normal bacteria in growth process absorbed and utilized the sugar in the medium.

\section{Leakage of nucleic acid}

As shown in Fig. 3. The ratio of OD that the bacteria suspension treated with VEE and VBF compared with control

Table 4 Antibacterial activities of ethanol extracts of valonia and shell from Q. variabilis

\begin{tabular}{|c|c|c|c|c|c|}
\hline \multirow[t]{2}{*}{ Microorganisms } & \multicolumn{5}{|c|}{ Inhibition zone (mm) } \\
\hline & Valonia & Shell & Punica granatum & Chloramphenicol & DMSO \\
\hline S. aureus & $10.89 \pm 0.12^{a}$ & $8.99 \pm 0.22^{a}$ & $10.22 \pm 0.18^{a}$ & $24.83 \pm 0.61^{a}$ & - \\
\hline S. paratyphi A & $12.37 \pm 0.36^{a}$ & $9.62 \pm 0.16^{a}$ & $10.30 \pm 0.21^{a}$ & $29.96 \pm 0.01^{a}$ & - \\
\hline S. typhimurium & $10.32 \pm 0.33^{a}$ & $8.69 \pm 0.12^{a}$ & $9.95 \pm 0.19^{a}$ & $27.10 \pm 0.74^{a}$ & - \\
\hline S. enteritidis & $9.52 \pm 0.28^{a}$ & $8.56 \pm 0.07^{a}$ & $9.35 \pm 0.25^{a}$ & $33.96 \pm 0.62^{a}$ & - \\
\hline L. monocytogenes & $9.36 \pm 0.32^{a}$ & $8.88 \pm 0.08^{a}$ & $10.83 \pm 0.17^{a}$ & $26.36 \pm 0.85^{a}$ & - \\
\hline
\end{tabular}

Each value represented in tables are means \pm SD $(n=3) .{ }^{a}$ correlation is significant at the 0.01 level compared with the negative control (DMSO). 
Table 5 Antibacterial activities of valonia and shell extracts from Q. variabilis against S. aureus and S. paratyphi A

\begin{tabular}{|c|c|c|c|c|c|c|c|}
\hline \multicolumn{2}{|c|}{ Samples } & \multicolumn{2}{|c|}{ Inhibition zone (mm) } & \multicolumn{2}{|c|}{$\mathrm{MIC}(\mathrm{mg} / \mathrm{ml})$} & \multicolumn{2}{|c|}{$\mathrm{MBC}(\mathrm{mg} / \mathrm{ml})$} \\
\hline & & S. aureus & $\overline{\text { S. paratyphi A }}$ & S. aureus & $\overline{\text { S. paratyphi A }}$ & S. aureus & $\overline{\text { S. paratyphi A }}$ \\
\hline \multirow[t]{5}{*}{ Valonia } & VEE & $10.89 \pm 0.12^{\mathrm{a}}$ & $12.37 \pm 0.36^{a}$ & 0.625 & 1.25 & 0.625 & 1.25 \\
\hline & VPEF & ND & $7.62 \pm 0.43^{\mathrm{a}}$ & $>10$ & $>10$ & $>10$ & $>10$ \\
\hline & VEAF & $11.64 \pm 0.43^{\mathrm{a}}$ & $12.26 \pm 0.12^{\mathrm{a}}$ & 1.25 & 2.5 & 1.25 & 2.5 \\
\hline & VBF & $12.26 \pm 0.14^{a}$ & $15.92 \pm 0.44^{\mathrm{a}}$ & 0.625 & 1.25 & 0.625 & 1.25 \\
\hline & WWF & $9.71 \pm 0.18^{\mathrm{a}}$ & $10.25 \pm 0.14^{a}$ & 0.625 & 1.25 & 0.625 & 1.25 \\
\hline \multirow[t]{5}{*}{ Shell } & SEE & $8.99 \pm 0.22^{a}$ & $9.62 \pm 0.16^{a}$ & 2.5 & 5 & 2.5 & 5 \\
\hline & SPEF & ND & ND & $>10$ & $>10$ & $>10$ & $>10$ \\
\hline & SEAF & $7.97 \pm 0.11^{\mathrm{a}}$ & $8.72 \pm 0.14^{a}$ & 5 & 2.5 & 5 & 5 \\
\hline & SBF & $7.06 \pm 0.01^{a}$ & $7.86 \pm 0.11^{a}$ & 2.5 & 2.5 & 2.5 & 2.5 \\
\hline & SWF & $8.01 \pm 0.05^{a}$ & $8.07 \pm 0.09^{\mathrm{a}}$ & 2.5 & 2.5 & 2.5 & 2.5 \\
\hline \multicolumn{2}{|c|}{ Punica granatum } & $10.22 \pm 0.18^{\mathrm{a}}$ & $10.30 \pm 0.21^{a}$ & - & - & - & - \\
\hline \multicolumn{2}{|c|}{ Ellagic acid } & $10.24 \pm 0.14^{a}$ & $11.45 \pm 0.25^{\mathrm{a}}$ & - & - & - & - \\
\hline \multicolumn{2}{|l|}{ DMSO } & - & - & - & - & - & - \\
\hline
\end{tabular}

Each value represented in tables are means \pm SD $(n=3) .{ }^{a}$ correlation is significant at the 0.01 level compared with the negative control (DMSO). ND Not determined with this extract.

were plotted versus time. VEE and VBF increased the OD value to 1.64-5.39-fold compared with that of untreated bacteria. For two bacteria strains, the amount of 260 $\mathrm{nm}$ absorbing material released with addition of VEE was different. After $8 \mathrm{~h}$ incubation for S. paratyphi A, the amounts reached the maximum, while it was after $4 \mathrm{~h}$ for S. aureus. The amounts of $260 \mathrm{~nm}$ absorbing material of $S$. aureus suspension tended to decreased during incubation from $8 \mathrm{~h}$ to $24 \mathrm{~h}$, and for $S$. paratyphi $\mathrm{A}$, it was at $24 \mathrm{~h}$. The decrease might be due to previously mentioned precipitation process and the adsorption of the $260 \mathrm{~nm}$ absorbing material on the precipitates. These precipitates were filtered out prior to the OD measurement.
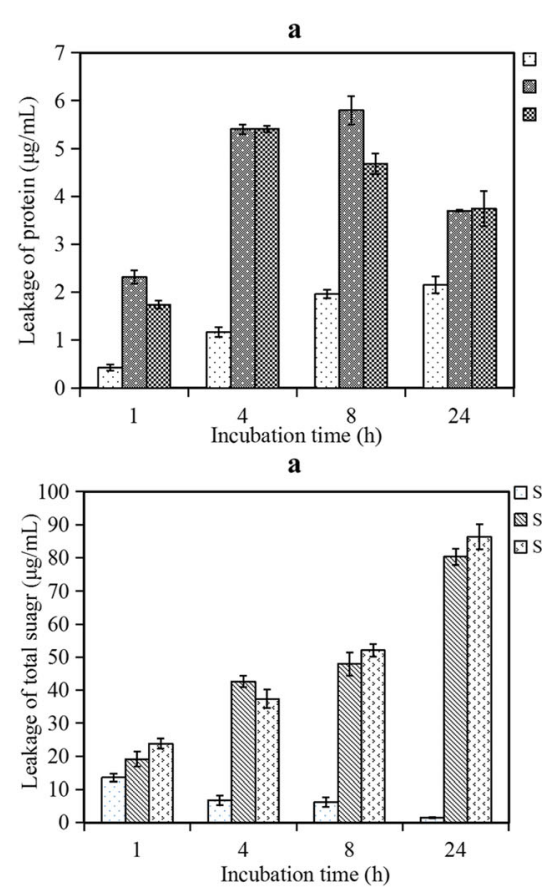

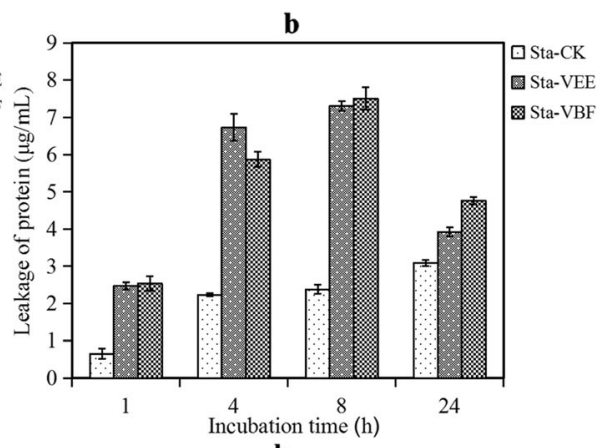

b

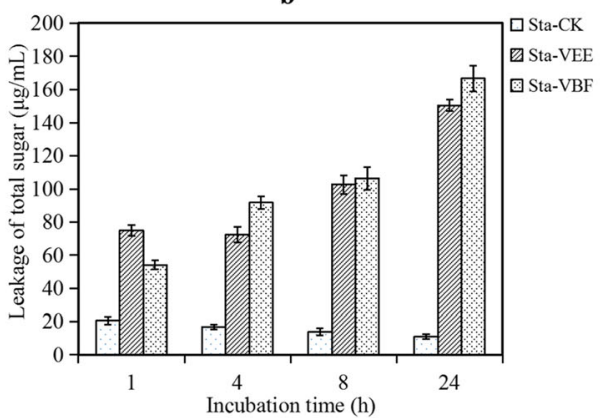

Fig. 2 Leakage of protein and total sugar from S. paratyphi A (Sal, a) and S. aureus (Sta, b) cells treated with VEE and VBF 

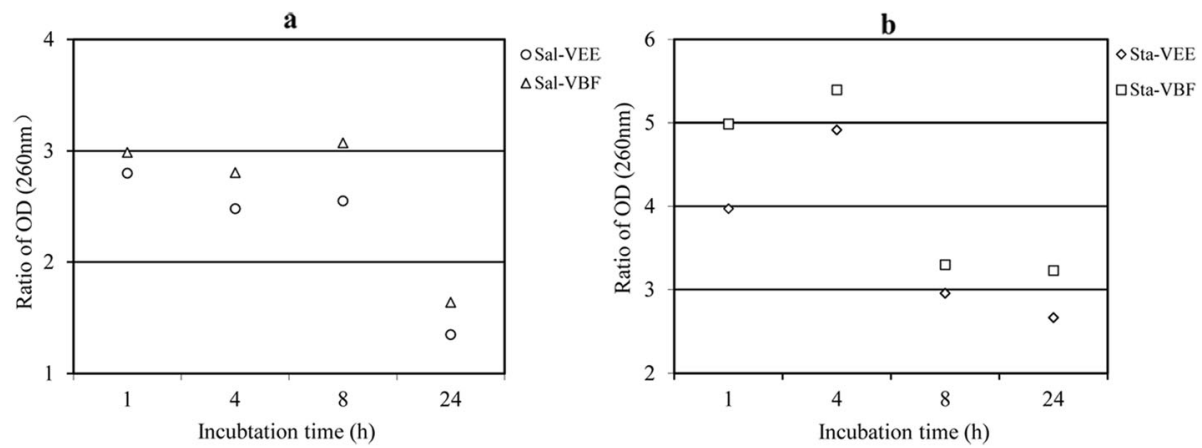

Fig. 3 Leakage of nucleic acid from S. paratyphi A (Sal, a) and S. aureus (Sta, b) cells treated with VEE and VBF

\section{The phosphorus metabolism of bacteria}

The results indicated that the consumption of phosphorus of $S$. aureus and S. paratyphi A that treated with VEE and VBF decreased with the incubation time (Fig. 4). It manifested that the phosphorus metabolism was seriously affected by the extracts and the VEE and VBF not only can destroy the membrane, but also affect the cell metabolism and growth situation.

\section{The protein of SDS-PAGE profiles}

As shown in Fig. 5, the protein profiles of the bacteria that treated with VEE and VBF significantly differed from that of the control. S. aureus and S. paratyphi A had more and much clearer protein bands than the control groups $(\mathrm{a} 0, \mathrm{~b} 0)$. After the treatment with the extracts at MIC value for $24 \mathrm{~h}$, the bacterial protein bands faded and some even disappeared. It implied that VEE and VBF had a remarkable effect on bacterial proteins.

\section{Electron microscope observation}

SEM micrographs revealed changes to the morphological and the outer surface of bacterial cells exposed to the extracts for $24 \mathrm{~h}$ (Fig. 6). The surfaces of all untreated cells were intact and smooth (Fig. 6a, d). S. paratyphi A cells untreated with the extracts had a uniform rodshaped appearance (Fig. 6a), and S. aureus cells grown in the absence of the extracts had a uniform bulbous shape (Fig. 6d). In contrast, S. paratyphi A cells that treated with VEE and VBF showed severe morphological destruction. Some treated bacterial cells became adhesive to each other and was highly distorted (Fig. 6b, c), which may lead to the leaching out of nutrient and genetic materials. For $S$. aureus cells, pore formation and cell lysis were also apparent after the treatment. Disintegration of some cells and presence of debris in the vicinity of treated cells were also observed (Fig. 6e, f). The results indicated that VEE and VBF may have severe effects on the cytoplasmic membrane and cell wall. However, these changes in more details still need to be further observed.

\section{Discussion}

As the Fagaceae family of plants is known to possess a large number of polyphenols [38], we determined the TPC of $Q$. variabilis since this plant also belongs to Fagaceae. The result differed from the other reports on the high chemical levels of phenolics of acorns from different Quercus species, namely Quercus suber [39]. Therefore, Quercus suber and Q. variabilis are the same genus, but to some extent, the same genus exists difference may be due to different species and extraction method.
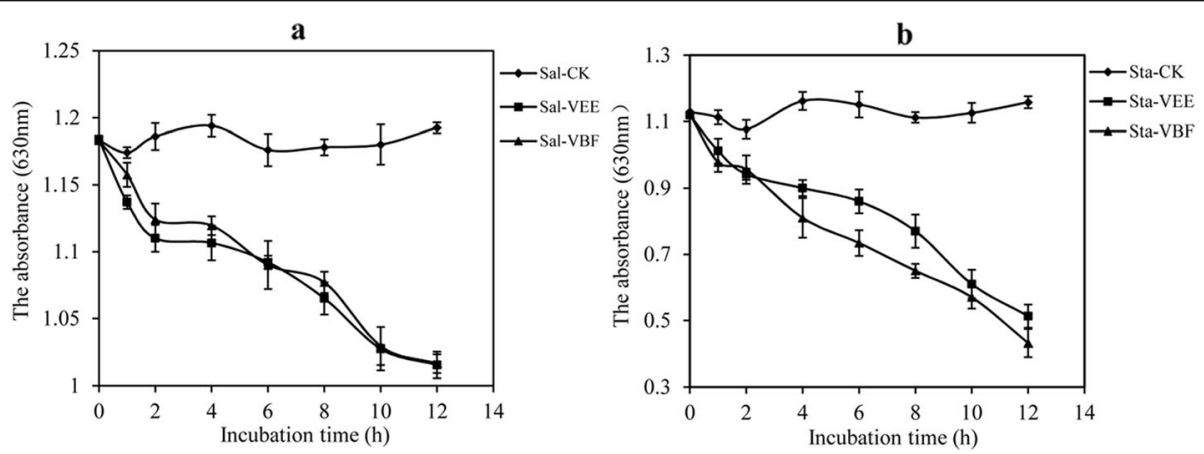

Fig. 4 Effects of VEE and VBF on the phosphorous metabolism of S. paratyphi A (Sal, a) and S. aureus (Sta, b) 


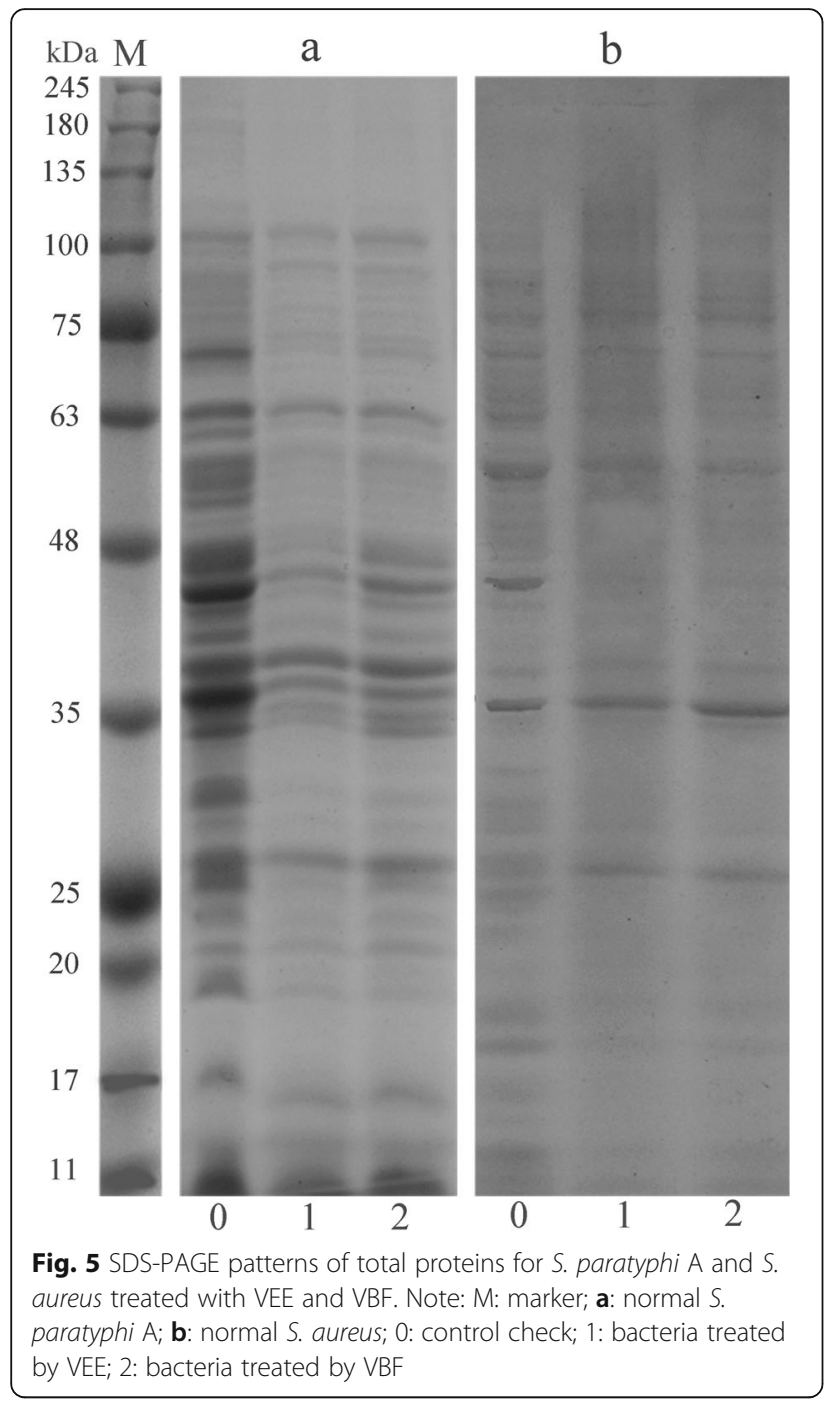

Chromatograms of valonia and shell extracts from $Q$. variabilis were analyzed by HPLC method. Previous researchers revealed the valonia is rich tannins in which the ellagic acid and luteic acid has been widely used in medicines and foods [21, 22]. Similarly, the ellagic acid existed in the acorn of valonia of Q. variabilis. Moreover, theophyline and caffeic acid were detected in acorn of Quercus suber [15], and they also existed in valonia and shell of $Q$. variabilis, so it showed that the chemical composition of the same genus had the similarity. Since only four compounds have been found in the extracts by RP-HPLC method. The identification of the other compounds needed to be further studied by spectrum method.

However, the leaves of $Q$. variabilis contains rich triterpenoid compounds in which 9 compounds (lupeol, friedlin, $\beta$-sitosterol, daucosterol, taraxerol, 3-epicycleucalenol, 3epicycloeucalenol-24-one, 3-epicycloeucalenyl-acetate and valiabilisic acid) were identified [20], yet none of them was detected in the valonia and shell of $Q$. variabilis in our study.

In general, the three parameters (DIZ, MIC and MBC) were used to determine the antibacterial activity $[4,6]$. In our assay, the antibacterial activities of the ethanol extracts of valonia and shell against five bacteria were studied by DIZ to process the preliminary screening of strains. The $S$. aureus and S. paratyphi A were chosen for further research of the antibacterial activities and related mechanism. The antibacterial activities (MIC and $\mathrm{MBC}$ ) of ten fractions (VEE, VPEF, VEAF, VBF, VWF, SEE, SPEF, SEAF, SBF, SWF) against $S$. aureus and $S$. paratyphi A were evaluated. In terms with the antibacterial activity (MIC and MBC), VEE, VBF and VWF showed similar activity. At the same time, we considered the DIZ. The result showed that VWF had the weaker
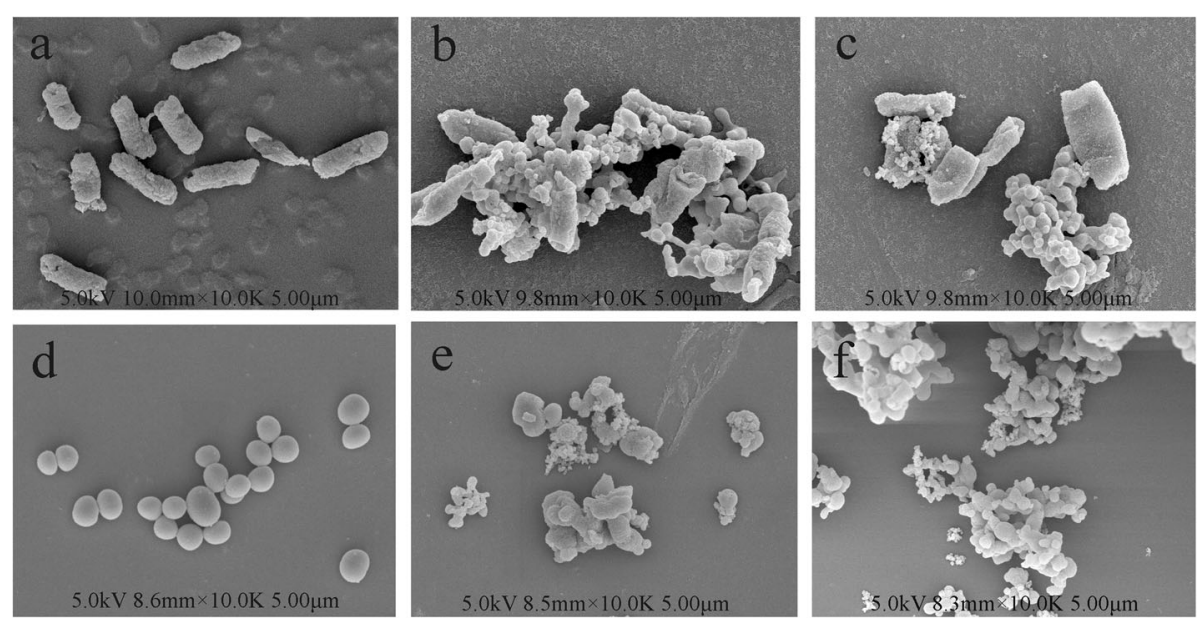

Fig. 6 Metamorphic structure of S. paratyphi A and S. aureus treated with VEE and VBF. Note: a: normal S. paratyphi A; b: S. paratyphi A treated by VEE; c: S. paratyphi A treated by VBF; d: normal S. aureus; e: S. aureus treated by VEE; f: S. aureus treated by VBF 
antibacterial activity compared to VEE and VBF, so VWF was not chosen for further assays. VEE and VBF were chosen to further study the mechanism.

In this study, since the ellagic acid was reported with antioxidant, antibacterial and anti-inflammatory activities, we determined the antibacterial activity of ellagic acid [40]. The inhibition zones of ellagic acid against $S$. aureus and S. paratyphi A were $11.45 \pm 0.25 \mathrm{~mm}$ and $10.24 \pm$ $0.14 \mathrm{~mm}$, below than that of VEE and VBF. Meanwhile, the RP-HPLC analysis indicated that ellagic acid was rich in VEAF, but the antibacterial effect of VEAF was lower than VEE and VBF. It suggested that ellagic acid was not the main antibacterial activities composition.

The cell membrane is an important part of bacteria. It plays an important role in maintaining normal bacterial life by balancing material and energy. It can stop the exogenous material entering and prevent the internal material leaking [41]. Sugar is the exogenous nutrients that provides primary carbon source and energy reserves material to bacteria. In normal physiological situation, the bacteria can absorb and utilize the exogenous nutrients, and the cellular content would leak after the membrane structure was damaged [33], so evaluation of cell leakage markers including absorbance at $260 \mathrm{~nm}$ for nucleic acid and determination of protein and sugar are indicators of membrane integrity. The leakage of nucleic acid through the bacteria membrane and the total sugar in the medium indicated that VEE and VBF had effects on the membrane of bacteria. The results of the leakage of sugar and nucleic acid were in agreement with some other antimicrobials treated on bacterial cells [33, 42].

Phosphorus is the necessary microelement and important constituent part of nucleic acid, phospholipid and sugar metabolism of microorganism and the cellular energy metabolism. The bacteria could utilize the glucose and go through a series of phosphorylation to provide the energy needed [33]. It is as expected that this is consistent with our results. The normal transportation of secretory proteins plays an important role in the growth of bacteria and in the life activity of bacterial cells [5]. When S. aureus and S. paratyphi A were treated with VEE and VBF for a certain time, protein contents in the supernatant were higher than their respective control. It stated that VEE and VBF cause the permeabilizing action. To further confirm it and to better understand the action, S. aureus and S. paratyphi A were further analyzed by SDS-PAGE for their soluble protein. The results indicated that VEE and VBF had a remarkable effect on bacterial proteins either by inhibiting their synthesis or destroying them, resulting in their death. SEM micrographs can intuitively reflect the morphological alterations of the bacteria membrane [4]. The results indicated adverse effects of VEE and VBF towards the cell of $S$. aureus and S. paratyphi A as compared to the control groups. Moreover, impaired membrane structure was revealed at higher extract concentrations. It may be due to lysis of membrane and transformation caused by the damage on the permeability and integrity of membrane from the samples.

\section{Conclusions}

The results indicated that valonia and shell of $Q$. variabilis possessed higher content of phenolic compositions and tannins, in which the ellagic acid is abundant in valonia extracts. VEE and VBF showed the best antibacterial activities against $S$. paratyphi A and S. aureus and the results of antibacterial mechanism showed that the extracts could damage the membrane of bacteria and result in great leakage of protein and nucleic acid of bacterial cells as well as the total sugar in the medium. Measurements of the SDSPAGE profiles confirmed the disruptive action of the on cytoplasmic membrane. Meanwhile, the damage of cell membrane was in accordance with that of SEM. It could be conferred that integrity of cell membrane would be an important factor to inhibit the bacterial normal growth and cellular metabolism. Therefore, this study suggested possible applications of valonia from $Q$. variabilis as natural antimicrobials or preservatives in the food and medicine field. In this study, ellagic acid was not the main antibacterial material so the antibacterial substances of VEE and VBF need to be further extracted, isolated and identified. Further research on molecular cytology level was needed to comprehensively investigate the antibacterial mechanism and find the specific target of substance, which could provide the theoretical basis for development and utilization of $Q$. variabilis resources.

\section{Abbreviations \\ L. monocytogenes: Listeria monocytogenes; MBC: Minimum bactericidal concentration.; MIC: Minimum inhibition concentration; Q. variabilis: Quercus variabilis; S. aureus: Staphylococcus aureus; S. enteritidis: Salmonella, L. enteritidis; S. paratyphi A: Salmonella, paratyphi A; S. typhimurium: Salmonella typhimurium; SBF: the n-butanol fraction of shell; SEAF: the ethyl acetate extracts of shell; SEE: the ethanol crude extract of shell; SEM: scanning electron microscopy; SPEF: the petroleum ether extracts of shell; SWF: the water extracts of shell; TFC: the total flavonoid content; TPC: the total phenolic content; TTC: the total tannin content; VBF: the n-butanol fraction of valonia; VEAF: the ethyl acetate extracts of valonia; VEE: the ethanol crude extracts of valonia; VPEF: the petroleum ether extracts of valonia; WF: Water fraction of valonia}

\section{Acknowledgements}

Not applicable

\section{Authors' contributions}

All authors have read and approved the manuscript. DMW and DWL conceived and designed the experiments. DZ and ZHL performed the experiments and analyzed the data. LNY and WW helped with the HPLC analysis experiment, SDS-PAGE experiment and the electron microscope observation. DZ, ZHL and DMW wrote the paper. DMW critically revised the paper.

\section{Funding}

This work was supported by the program from the Special Fund for Forestry Scientific Research in the Public Interest of China (201504320). 


\section{Availability of data and materials}

The datasets supporting the conclusions of this article are included within the article. The voucher specimen was identified by the professor Dengwu Li and was deposited at Herbarium of the Northwest A\&F University, Yangling, China (WUK 0489424).

\section{Ethics approval and consent to participate}

Not applicable.

\section{Consent for publication}

Not applicable.

\section{Competing interests}

All the authors declare no present or potential conflicts of interest. Al authors are responsible for the content and writing of the paper and approved of its publication.

Received: 23 June 2019 Accepted: 20 September 2019 Published online: 18 October 2019

\section{References}

1. Bansal S, Choudhary S, Sharma M, Kumar SS, Lohan S, Bhardwaj V. Tea: a native source of antimicrobial agents. Food Res Int. 2013;53:568-84.

2. Cartea ME, Francisco M, Soengas P, Velasco P. Phenolic compounds in Brassica vegetables. Mol. 2011;16:251-80.

3. Arques JL, Rodriguez E, Nunez M, Medina M. Inactivation of gramnegative pathogens in refrigerated milk by reuterin in combination with nisin or the lactoperoxidase system. Eur Food Res Technol. 2008;227:77-82.

4. Zhang YB, Liu XY, Wang YF, Jiang PP, Quek SY. Antibacterial activity and mechanism of cinnamon essential oil against Escherichia coli and Staphylococcus aureus. Food Control. 2016;59:282-9.

5. Wang CJ, Chang T, Yang H, Cui M. Antibacterial mechanism of lactic acid on physiological and morphological properties of Salmonella enteritidis, Escherichia coli and Listeria monocytogenes. Food Control. 2015;47:231-6.

6. Ben HA, Trigui M, Ben MR, Jarraya RM, Damak M, Jaoua S. Chemical composition, cytotoxicity effect and antimicrobial activity of Ceratonia siliqua essential oil with preservative effects against Listeria inoculated in minced beef meat. Int J Food Microbiol. 2011;148:66-72.

7. Tian J, Zeng XB, Feng ZZ, Miao XM, Peng XM, Wang YW. Zanthoxylum molle Rehd. Essential oil as a potential natural preservative in management of Aspergillus flavus. Ind Crop Prod. 2014;60:151-9.

8. Fleming-Jones ME, Smith RE. Volatile organic compounds in foods: a five year study. Agric Food Chem. 2003;51:8120-7.

9. Andersson DI. Persistence of antibiotic resistant bacteria. Curr Opin Microbiol. 2003;6:452-6.

10. Borges A, Ferreira G, Saavedra MJ, Simoes M. Antibacterial activity and mode of action of ferulic and gallic acids against pathogenic bacteria. Microb Drug Resist. 2013:19:256-65.

11. Wang ZX. Quercus variabilis Blume. Life World. 1974;3:7 (In Chinese).

12. Duan CR, Li SY, Mao ZL. Protect and develop Quercus variabilis Blume forest. J Henan Agric Sci. 1980;10:22-4 (In Chinese)

13. Zheng $\mathrm{CH}$, Mason EG, Jia LM, Wei SP, Sun CW, Duan J. A single-tree additive biomass model of Quercus variabilis Blume forests in North China. Trees. 2015;29:705-16

14. Cookb GB. Cork and cork products. Econ Bot. 1948:2:393-402.

15. Pereira H. Chemical composition and variability of cork from Quercus suber L. Wood Sci Technol. 1988;22:211-8.

16. Lei YF, Jia T, Song XZ. Chemical composition of cork from Quercus variabilis. Wood Fiber Sci. 2012:44:214-9.

17. Miranda I, Gominho J, Pereira H. Cellular structure and chemical composition of cork from the Chinese cork oak (Quercus variabilis). J Wood Sci. 2013:59:1-9.

18. Xie BX, Xie T. Exploitation study of acorn resources in China. J Cent South For Univ. 2002;22:37-42 (In Chinese).

19. Zhou JY, Lin J, He JF, Zhang WH. Review and perspective on Quercus variabilis research. J Northwest For Univ. 2010;25:43-9 (In Chinese).

20. Zhou LH. Research on the pharmacognosy of Quercus variabilis. Shen Yang Pharm Univ. 2000;3:179-81 (In Chinese).

21. Shan SX, Wang BC, Li DH. The tannin component of valonia from Quercus variabilis: the isolation and identification of ellagic acid. Chem Ind Forest Pro. 1983:4:40-7 (In Chinese).
22. Shan SX, Wang BC, Li DH. Research on the components and structure of hydrolysable tannin: the isolation and identification of IV luteoic acid. J Sichuan For Sci Technol. 1984;2:1-7 (In Chinese).

23. Wen TS. The cultivation and use of Quercus variabilis. For by-prod spec China. 1991;2:29 (In Chinese).

24. Yang LN, Wang DM, Zhou D, Zhang YW. Effect of different isolation methods on structure and properties of lignin from valonea of Quercus variabilis. Int J Biol Macromol. 2016:85:417-24.

25. Zhang YJ, Luo ZW, Wang DM, He FY, Li DW. Phytochemical profiles and antioxidant and antimicrobial activities of the leaves of Zanthoxylum bungeanum. Sci World J. 2014;20014:181072.

26. Wang SS, Wang DM, Pu WJ, Li DW. Phytochemical profiles, antioxidant and antimicrobial activities of the leaves of three Potentilla species. BMC Complement Altern Med. 2013;13:321-32.

27. Dudt JF, Shure DJ. The influence of light and nutrients on foliar phenolics and insect herbivory. Ecol. 1994;75:86-98.

28. Lu R, Hemar Y, Perera CO, Lewis G, Krissansen GW, Buchanan PK. Antibacterial and antioxidant activities of aqueous extracts of eight edible mushrooms. Bioact Carbohydr Diet Fibre. 2014;3:41-51.

29. Khodja NK, Makhlouf LB, Madani K. Phytochemical screening of antioxidant and antibacterial activities of methanolic extracts of some Lamiaceae. Ind Crop Prod. 2014:61:41-8.

30. Kamruzzaman M, Bari SMN, Faruque SM. In vitro and in vivo bactericidal activity of Vitex negundo leaf extract against diverse multidrug resistant enteric bacterial pathogens. Asian Pac J Trop Med. 2013;6:352-9.

31. Bradford MM. A rapid and sensitive method for the quantitation of microgram quantities of protein utilizing the principle of protein-dye binding. Anal Biochem. 1976;72:248-54.

32. Chen CZS, Cooper SL. Interactions between dendrimer biocides and bacterial membranes. Biomaterials. 2003;23:3359-68.

33. Qian LH, Tao Y, Xie J. Antimicrobial mechanism of tea polyphenol against Staphyloccocus aureus and Pseudomonas aeruginosa. Microbiol China. 2010; 37:1628-33 (In Chinese).

34. Zhai P, Han JH. H LX, Yue GW and Shi YH. Investigate antibiosis dynamics and antibacterial mechanisms of antibacterial peptides from Musca domestica larvae. Chin Biotechnol. 2006;26:33-9 (In Chinese).

35. Zhao L, Zhang HY, Hao TY, Li S. In vitro antibacterial activities and mechanism of sugar fatty acid esters against five food-related bacteria. Food Chem. 2015:187:370-7.

36. Lv F, Liang H, Yuan QP, Li CF. In vitro antimicrobial effects and mechanism of action of selected plant essential oil combinations against four foodrelated microorganisms. Food Res Int. 2011:44:3057-64.

37. Al-Zoreky NS. Antimicrobial activity of pomegranate (Punica granatum L.) fruit peels. Int J Food Microbiol. 2009:134:244-8.

38. Guan XL, Yang ZM, Yan XJ, Liu CL, Liu JL, Huang YL, Li DP. Content and antioxidant activity of polyphenols from 8 Fagaceae plants. Chin J Exp Tradit Med Formulae. 2015;21:65-9 (In Chinese).

39. Custódio L, Patarra J, Alberício F, Neng NR, Nogueira JMF, Romano A. Phenolic composition, antioxidant potential and in vitro inhibitory activity of leaves and acorns of Quercus suber on key enzymes relevant for hyperglycemia and Alzheimer's disease. Ind Crop Prod. 2015;64:45-51.

40. Li ZJ, Guo X, Dawuti G, Aibai S. Antifungal activity of ellagic acid in vitro and in vivo. Phytother Res. 2015;29:1019-25.

41. Zou L, Hu YY, Chen WX. Antibacterial mechanism and activities of black pepper chloroform extract. J Food Sci Technol. 2015;52:8196-203.

42. Lee SY, Lim SI, Ahn DH. Antibacterial mechanism of Myagropsis myagroides extract on Listeria monocytogenes. Food Control. 2014:42:23-8.

\section{Publisher's Note}

Springer Nature remains neutral with regard to jurisdictional claims in published maps and institutional affiliations. 